\title{
Serving the peace? Disorder, order and peace in church polity
}

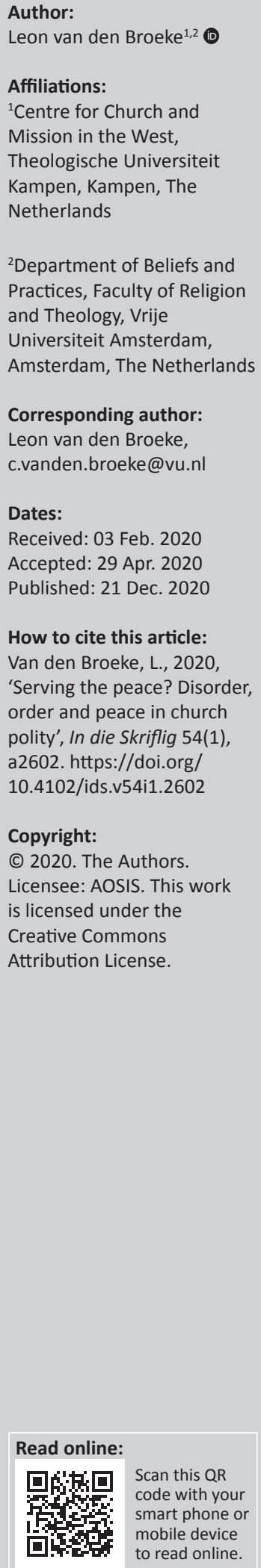

If a church order rules that the peace should be served, what does that mean? It is the aim of this contribution to deal with the legal history of the phrase 'to serve the peace' as from the 16th-century Reformed synodical acts and church orders. This includes an understanding of

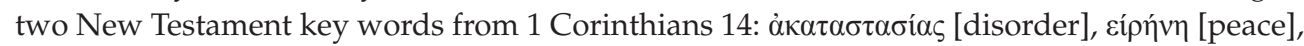

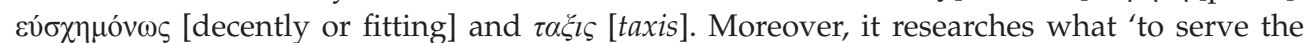
peace' means in situations of ecclesiastical and societal injustice. Therefore, the expertise of both scholars in church polity, law and New Testament will be included. Also, this contribution focuses on the question whether church orders are or ought to be peace church orders. This is not to ignore conflict, disunity and struggle, but to relate to it and overcome this. With the assistance of a church order, a church should fight injustice and disorder and foster peace. This is an assignment for the church and for interpersonal relationships. However, it is also a divine gift, as church polity should not overlook the eschatological dimension of peace. Church order might prevent the survival of the fittest in the church. Church polity might indeed create peace and overcome injustice. The opposite of disorder is not order, or more order in the sense of overregulation, but peace that can be restored by church polity.

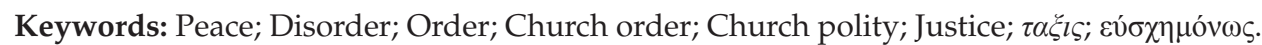

\section{Introduction}

'In the church of Christ everything must be in a fitting and orderly way, so that the peace is being served' (Kerkorde GKv 2017:4). The first part of this rule is well known, but it was the second part of this rule-zodat de vrede wordt gediend - of the church order of the Reformed Churches Liberated (Gereformeerde Kerken vrijgemaakt) which caught my attention a couple of years ago (Kerkorde GKv 2017), in Dutch:

\section{A2 vrede}

A2.1 In de kerk van Christus moet alles op gepaste wijze en in goede orde gebeuren, zodat de vrede wordt gediend. [In the church of Christ, everything needs to be performed fittingly and in good order. Its purpose is to serve the peace.] [author's own translation].

A2.2 Allen staan onder de ene Heer, Jezus Christus, het hoofd van zijn kerk. Geen persoon of kerk mag een andere persoon of kerk overheersen. [This is important because there should not be any lordship in the church. There is only one Lord and Head of the church: Jesus Christ.] (p. 4, [author's own translation])

The Reformed Churches Liberated, a result of the secession of 1944, called Vrijmaking, retained the Dordt Church of 1619, and also the minor changes which the former united Reformed Churches in the Netherlands had maintained between 1892 and 1944. In 1978, the Reformed Churches Liberated revised the church order, but it still retained both the content and the framework of the Dordt Church Order of 1619. In 2015, this changed when a revised church order became valid, or perhaps one could say: a new church order, particularly in its composition, while the content still resembles the Dordt Church Order of 1619.

I started exploring this (re)new(ed) church order and read it over and over again. This church order does not contain four chapters like in the Dordt Church Order of 1619, but eight chapters. As said, the second section of this church order (section A2) particularly caught my attention, both because of its title 'peace' and because of the words 'so that the peace is being served'. Because of limited space, I will focus on peace and Reformed church polity. This does not mean that other church polity systems would not foster peace. For example, canon $287 \S 1$ of the Codex Iuris Canonici states, 'Most especially, clerics are always to foster the peace and harmony based on justice which are to be observed among people' (CIC 1983). This canon not only emphasises the 
fostering of peace, but also harmony based on justice. There can be no peace and harmony without justice.

A focus on (serving the) peace can easily lead to the misunderstanding that the ecclesiastical reality that contradicts peace is absent or ignored. This is not the case. Maybe it is even the other way around: there are so many conflicts in churches that we accept it as something inevitable or belonging to the church. The history of Dutch and other Calvinist churches, including the Reformed Churches in the Netherlands Liberated, is a history of struggle, conflict and disunity. Unfortunately, the book of Reformed church history includes many black pages. The churches live East of Eden, in a broken world. They have to take into account that they, their office-bearers and their congregants are far from perfect. There are conflicts, disharmony and disorder. Office-bearers and church members run into troubles, fight with each other and take the other party to court. It is a sad story with no conflict solution. Although we also need to add that in some cases, people overcome their conflicts and come to resolution. The purpose of my contribution is not to ignore the ecclesiastical reality and to overlook the unsolved conflicts and problems, also not to draw an ideal picture. The aim is rather to see what in cases of the absence of peace and order can be the contribution from the perspective of Reformed church polity to realise peace and order.

It is the aim of this contribution to deal with the origin of the phrase 'to serve the peace', what it means in situations of ecclesiastical and societal injustice, and whether church orders are or ought to be peace church orders. In doing so, I reflect on the theme of the conference, 'On doing what is just, right and fair'. This contribution includes subsequent paragraphs on the origin of the phrase, 'so that the peace is being served', the legal history of this phrase and its meaning, and church orders as orders of peace, before the final paragraph.

\section{The origin}

Although the word 'peace' is in a prominent way present in the second section of the 2015 church order, it is only mentioned in two other sections: on church visitation, particularly the peace between [local] churches (E65) (Kerkorde GKv 2017:15) and on peace through law (F75) (Kerkorde GKv 2017:18). Article E65.2 rules that the aim of visitation is to advise, encourage and discipline office-bearers with view to the edifying of the congregation and the peace between the churches. Article F75.1 mentions that ecclesiastical judicial process is focused on restoration of the peace by law.

The predecessor of this church order, the church order of 1978, also included the word 'peace', but only once: in the section about church visitation (Kerkorde GKv 1978:8). It rules that the aim of the visitation is to discipline timely of office-bearers in case if a carelessness is ascertained, and to cooperate in word and deed to the peace, the edification and the well-being of the churches.
Did the Dordt Church Order of 1619 or one of its predecessors Emden 1571, Dordrecht 1574, Dordrecht 1578, Middelburg 1581 or The Hague of 1586 - refer in one way or the other to peace (DKO 1619)? Apart from two particular questions, the word 'peace' is absent in the subsequent acts and/or church orders between 1571 and 1586. It concerns (particular) question 51 of the acts of the Synod of Dordrecht 1578 and (particular) question 4 of the church order of the Synod of The Hague of 1586 (cf. Acta 1578:178-179; Kerkorde 1586:509). The word 'peace' appears for the first time in the Dordt Church Order of 1619. Section 44 states that the aim of the assistance and advice of church visitors is to be the peace, the edification and the preservation of the local churches and schools (DKO 1619).

The above-mentioned aim of church visitation is retained in subsequent revisions of the Dordt Church Order of 1619, as in 1905 (Kerkorde GKN 1905) and in 1933 (Kerkorde GKN 1933), but not in 1892 (Kerkorde GKN 1892), 1957 (Kerkorde GKN 1957) and 1971 (Kerkorde GKN 1971) in churches like the Reformed Churches in the Netherlands (Gereformeerde Kerken in Nederland), the Christian Reformed Churches (Christelijke Gereformeerde Kerken in Nederland) (Kerkorde CGK 2011), the Reformed Churches (Gereformeerde Gemeenten) and in the Reformed Churches Liberated (Gereformeerde Kerken vrijgemaakt). Also, Reformed churches around the globe applied the instrument of visitation as in article 44 of the Dordt Church Order, for example, the Gereformeerde Kerke in Suid-Afrika since the first synod in 1862.

\section{The meaning}

To answer the question of what the goal or assignment of peace means for situations of injustice, we first need to be clear of the meaning of section A2 concerning peace. At first sight, this section is not clear when it comes to peace. This section contains two parts. The second part concerns the anti-hierarchic rule, which refers to the very first section of the acts of the Synod of Emden of 1571. Its meaning is that there ought not to be lordship of one (local) church or office or office-bearer over another. It emphasises the autonomy of the local church much to the disadvantage of the supralocal church. According to gereformeerde church polity, there is not a supralocal church as in the (Dutch) Hervormde context, but only a confederation of local churches that gather through its delegated office-bearers. When they gather, it is not a meeting of offices or office-bearers, but a general assembly. The second rule should not be forgotten: the final section (86) of the Dordt Church Order of 1619 which says that the church order can only be adjusted by common consent (in Dutch: met gemeyn accoordt). When the first part prohibits lordship and promotes the autonomy and completeness (ecclesia completa) of the local church, the last part is a buffer and a warning against (Reformed) independentism. When the first part referred to and rejected 16th-century Roman-Catholic hierarchy, the last part referred to and rejected 16th-century Anabaptist independentism. Does this mean that we must understand 
the goal of peace as the avoidance by office-bearers and general assemblies of lording over one another? This might be the case. The second part of the second section of 2015 is an important elaboration of the first part.

However, that is not the whole picture. The first part of section A.2 states that in the church of Christ, everything needs to be performed in a fitting and orderly way. It is related to the first epistle of Paul to the Corinthians 14:40. The Greek word $\tau \alpha \xi i \varsigma$ [order] means: (1) a fixed succession of order, (2) (good) order, (3) position and (4) nature, quality, manner, condition and appearance (Gingrich \& Danker 1979:803-804). The word taxis comes from outside the Christian world and means the normal order in every aspect of life. Taxis in 1 Corinthians 14:40 is usually translated as 'in good order' or 'in an orderly way'. The South African expert in church polity C.J. Smit (1946-2011) concluded that taxis is both a gift and an assignment (1984:619). He focuses more on taxis, then on the Greek word

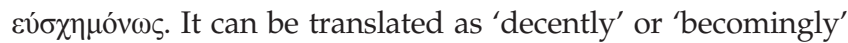
(Gingrich \& Danker 1979:327), or as in the New International Version (NIV) 'fitting', and in Afrikaans, 'wegvoeglik', 'paslik', 'geskik' or 'behoorlik' (Smit 1984:10). The New Testament scholar

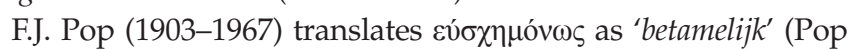
1974:343). It is the category of decency and decorum of the

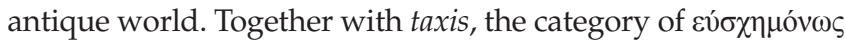
is used by Paul as the general convention, decency and decorum in the public life of the antique world for the ecclesiastical context.

Smit emphasises and explains the exegetical context of 1 Corinthians 14; moreover, he focuses on 1 Corinthians 12-14 and refers to the libertine influence of the gentiles on the young and vulnerable church in Corinth. A.J. Bronkhorst (1914-1994) also connects 1 Corinthians 14 with the charismata of 1 Corinthians 12 (Bronkhorst 1947:82-83). The fact that there are charismata in the church does not mean that disorder is neither the rule nor can be accepted. The context is that the young Corinthian church was divided. Alongside much disagreement the church had to solve the tension between on the one hand freedom to speak and on the other hand maintaining the peace in the church. A prophet in the church needed to be aware that he was not the only one in the church and needed to respect other prophets with the same divine gifts (Von Campenhausen 1953:67). The divine gifts need to edify the church and not create tension of division (cf. Lockwood 2000:502, 515; Garland 2003:664, 674). Smit also emphasises the word 'all', in Greek: $\pi \alpha{ }^{\prime} v \tau \alpha$ (1984:9-10). It means that the order concerns neither a couple of things, nor the glossolalia, and also not the question whether women are allowed to speak or not in the worship, but that order includes everything in the church (cf. Orr \& Walther 1976:304-305, 315; Lockwood 2000:502, 515). The Dutch theologian Koffeman (2014) states:

'In order' refers to a common understanding in the Hellenistic context of the New Testament that there is a relationship between 'what is good', 'harmony', 'world order' and God (cf. 1 Cor 14:33). (p. 15)
Koffeman connects verse 40 with verse 33. 1 Corinthians 14:33 states, 'For God is not a God of disorder but of peace as in all the congregations of the Lord's people' (NIV).

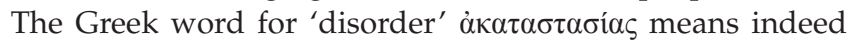
disorder, disturbance and unruliness (Gingrich \& Danker 1979:30; Schrage 1999:452). This relates to the question who is or are authorised to speak in the gatherings of the church. The Dutch professor in New Testament Herman N. Ridderbos (1909-2007) considered 'peace', the opposite of 'disorder', as a situation of 'well-being' or 'welfare' (Ridderbos 1965:197). According to him, it means that it becomes clear from the apostle Paul's vision on the maintaining of order and discipline in the church 'that it needs to reflect the nature of the church as the holy people of God and the in the visibility acting body of Christ' (Ridderbos 1966:522). The early Christian theologian Tertullian (Quintus Septimus Florius, ca. 160-230) was of the opinion that ecstasy is a feature of true spiritual inspiration. Nevertheless, he presented to Marcion of Sinope (ca. 85-160) that also the spirits of the prophets (he considered Marcion as a prophet as well) needed to submit to the (biblical) prophets because their characteristic is not disorder, but peace (Roukema 1996:211). As 1 Corinthians 14:33 and 40 have to be understood as an order for worshipping as it is focused on the Corinthians' context of prophecy and glossolalia, it is applied for all the aspects of the life of the church. There should not be overregulation in the church. Moreover, the Spirit and order should not be separated from one another (Ridderbos 1965:197; Schrage 1999:471-476; Van den Broeke \& Schaeffer 2019).

References to biblical key texts as 1 Corinthians 14:33 should include a reference to the Greek word for peace, síp ńv (Gingrich \& Danker 1979:227-228). Smit (1984) explains that this peace concerns the relationship between (1) people, (2) nations and (3) God and human beings (pp. 12-13). It corresponds with the Hebrew word welfare and health (Jenni \& Westermann 1984:919-934). It is not (only) focused on the individual welfare or well-being, but also harmony in society and within a community. It is not only about individual peace for the soul, but it also expresses (doing) biblical justice. Moreover, it is not only concerned with individual peace (of the soul), but also with salvation in the most broad sense of the word. It also means restoration of what has gone wrong or is broken. Smit (1984) expresses that 'peace' in 1 Corinthians 14:33:

$[H]$ et die spesifieke betekenis: waar daar vrede met God en met elkaar heers as 'n vrug van die heil in en deur Jesus Christus, daar kom orde as 'n gawe van God tot stand. Waar die sonde heers, is daar wanorde, maar waar God heers, is daar vrede [...] Die orde, dit wel sê die toestand wat onstaan in die kerk deur die gedrag ooreenkomstig die wet van Christus, is die vrug van vrede. (pp. 13-14)

Another South African expert in church polity, J.J. Van der Walt (1974), was of the same opinion:

Die apostel sê dus: God is 'n God van vrede en daarom van orde. 'Orde' beteken die vrede van harmonie in die organiese eenheid van die kerk met sy Hoof, want Hý is die vrede van die kerk (Ef. 2 : 14 e.v.). Daarom is die ganse Kerkorde ondergeskik aan én afhanklik van die 
Woord, want in die Woord word bepaal hoe die lewe in die vrede van Christus is. (p. 6)

As a New Testament scholar, Pop also has an eye for church order. He stated that a church order is appropriate because it protects the church for degeneration. A church order is also focused on the edifying of the church: 'The church order regulations of verses 26-40 are unequivocally geared towards this' (Pop 1974:337).

In the New Testament epistles, it is usually combined with

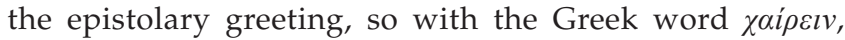
'grace and peace!', as, for example, in Romans 1:7, 1 Corinthians 1:3 and 2 Thessalonians 1:2 (Gingrich \& Danker 1979:227). It brings in the gift from God's gracefulness and heavenly peace for a broken world, and the assignment for the faithful to try to be gracious and graceful, being an instrument of peace. This gift and assignment does not limit itself to just one of the local church(es), not only to the confederation of the local churches (the supralocal church), but it also concerns nothing less than the church of Christ.

As was also mentioned above, section F75.1. reveals something about the restoration of peace through law. This is the aim of ecclesiastical trial. It is characterised by biblical wisdom and the conditions of fair and impartial jurisdiction: (1) to do precise research, (2) audi alteram partem [listen to the other side or party], (3) the right to be assisted by an advisor or counselor, (4) the possibility of hearing witnesses, (5) the possibility of consulting experts, (6) equal arms (equal access to relevant documents), (7) motivated written jurisdiction, (8) to achieve provision in urgent circumstances and (9) the right of substitution.

The response (in Dutch: Memorie van Antwoord) of the church order committee of the Reformed Churches Liberated stressed the notion of church polity as law serving the peace (Deputaten 2009:26). With view to the judicial process, the committee emphasised that the subsequent sections aim to serve the inner ecclesiastical peace, but also that nonetheless conflicts need to be dealt in an honest and a professional way (Deputaten 2009:27).

The law history of section A2.1 reveals that at first the rule was: 'In the congregation of Christ everything needs to be performed decently and in good order, so that the mutual peace will be served (...)' (Deputaten 2011:26). It was changed into: 'A2.1 In the church of Christ everything needs to be done decently and in good order, so that the peace will be served (...)' (Deputaten 2011:26). The reason for this adoption was that the church order committee did not strive for sweet peace (to keep the peace) in the church, but wanted to focus on the peace of Christ. In its explanation, the committee considered 1 Corinthians 14:40 together with 1 Corinthians 14:33 as the locus classicus for church polity (Deputaten 2009:28).
Peace, and not disorder, is of high importance for the Christian church, as it has been and still is for Jewish communities, as the Lutheran theologian and scholar of Judaism Paul Billerbeck (1853-1932) (1985:470) stated, 'An Bestimmungen über Schicklichkeit $u$. Ordnung in religiösen Dingen, speziell im gottesdienstlichen Leben, ist die alte Synagoge gerade nicht arm gewesen'.

The German church historian Hans E. Freiherr von Campenhausen (1903-1989) and the German jurist and expert in church polity Hans A. Dombois (1907-1997) emphasised that the opposite side of disorder is not - what many lay people and office-bearers might easily think order, but peace (Von Campenhausen \& Bornkamm 1959:6; Dombois 1969:3). Peace with God and the peace of God are the very nature and strength of the church because it comes from God and everything else opens from here and only from here (Von Campenhausen \& Bornkamm 1959:6). Dombois (1969:1009) is of the same opinion, 'Als Gegensatz von Unordnung erscheint nicht die positive Ordnung, sondern der Friede Gottes'. This does not mean that peace excludes, ignores or overrules order. The apostle Paul meant that there is disorder if people or things take place where God did not put them (Pop 1974:337). Senft (1979) writes that God's:

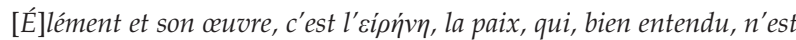
pas un ordre mort, mais l'ordre vivant que l'amour et le souci du bien des autres font régner dans la communauté. (p. 1982)

From this perspective, it is interesting that R. Dean Anderson (2012) gave his commentary on 1 Corinthians the subtitle, 'Orde op zaken in een jonge stadskerk'. The biblical peace does not only concern broken and restored relationships 'aber eben als Konsequenz (Rom 14,17) der eschatologischen sípฑiv im Heiligen Geest, die der "Gott der Liebe und des Friedens" (2 Kor 13,11) wirkt und erwartet' (Schrage 1999:457).

Although some experts in Reformed polity refer to such biblical passages in their explanation of the book of church order, in general, they write more about the practical side of the application of the church order for the ecclesiastical side. For example, in his commentary, Joh. Jansen (1873-1956) focused more on the practical regulations with view to church visitation. He (1952:202) did not explicitly make art. 44 clear when it comes to 'the peace'. In general, he stated, 'De visitatoren vormen een commissie van raad en hulp om eventuele moeilijkheden in het kerkelijk leven te voorkomen of intijds op te ruimen'. Apart from his biblical and historical explanation, Bouwman (1934) also hardly pointed to peace as belonging to the nature and goal of church visitation:

De ware visitator moet zijn een menschenkenner, die een juisten blik heeft in het leven, die het menschelijk hart kent, en die, bezield met de liefde van Christus, gaarne wil medewerken tot het welzijn van de kerk, en den opbouw van het lichaam van Christus. (p. 173)

However, he (1934) stated that the work of church visitors:

[Z]al onder Gods zegen dienstbaar zijn tot bevordering van den vrede en de liefde, tot meerdere samenwerking der broederen en den opbouw der gemeente en de verheerlijking van's Heeren naam. (p. 179) 
Bos (1950:168) pointed to one of the tasks of church visitors, namely, 'om geschillen bij te leggen'. Still, none of them explicitly explained what exactly is meant with serving the peace. The same goes for, among others, F.L. Rutgers, B. Spoelstra, J. Visser, K. De Gier and G. Van Rongen (De Gier 1989; Rutgers 1892; Spoelstra 1989; Van Rongen 2005; Visser 1999).

As might have been clear above, the church order committee of the Reformed Churches Liberated paid attention to the biblical connotation of 'serving the peace' in its considerations. The committee also stated that church polity is not something absolute or untouchable, but an instrument for the peace in the church. With this statement, it weakened its earlier revision of words 'the mutual peace' as 'peace' to avoid making the aim of church polity the sweet - inner ecclesiastical - peace but rather the peace of Christ. Furthermore, the committee's motive was that the higher aim of ecclesiastical jurisdiction is restoration of peace by law, so that the mutual peace must be served (Deputaten 2009:78). For this reason, it considered that the replacement of the word 'peace' with 'reconciliation' in F75 (previous F6.1) was not an improvement.

Also, to promote the material peace in the local church, the procedural peace was considered of high importance. Therefore, the ecclesiastical jurisdiction needs to be characterised by reference to Holy Scripture and honest jurisdiction. An expression of this Scriptural foundation is the golden rule of restoration of peace by law, which is urged by James 3:18, 'Peacemakers who sow in peace reap a harvest of righteousness' (NIV).

\section{Church order of peace?}

This is very much a miniature of a church order development regarding peace. It makes one curious about the bigger picture, and leads to the sub-question whether church orders are of ought to be orders of peace. Through the church order, the church should work against disorder and foster peace. It fights injustice, both in church and in society, as itconsiders injustice a sin against God and human race. The early-Christian writing $\Delta \mathrm{t} \delta \alpha \chi \eta$ - Didachè - also expressed the assignment and gift of peace in line with the New Testament: 'Do not [create] disunion, but bring peace to disputes' (Jefford 2013:27-28). And: 'And do not correct one another in anger but in peace, as you have in the gospel' (Jefford 2013:46).

These are beautiful lines, but peace, including justice, is often the expected, but absent guest, also in the church. Sometimes, disappointment, disorder and disgrace seem to rule. Ideally, as John Calvin (1509-1564) pointed out, the church is a Eucharistic community (CO 1871:5; cf. Van den Broeke 2018:3). It does not mean in the Donatist' way of thinking that church members first become saints before passing the Reformed doctrinal exam and being admitted to the table, but to experience and learn how to spell out, integrate and internalise God's grace and peace. Still, there is, and will be, sin in the church in a variation of the title of one of Rik Torfs' book De kardinaal heeft verdriet (Torfs 2002). One could easily state that the congregant is grieving. Many parishioners inside and outside the Roman Catholic Church find themselves in such a situation because of ecclesiastical injustice, the absence of peace, not to speak of disgrace and disorder.

There is always the decoy of having a too low or a too high expectation of law, of church polity, of restoration of peace through law. Law is important because it 'sichert die Freiheit, begrenzt aber auch diese Freiheit am Recht des anderen und am Anspruch der Gemeinschaft' (cf. Scheuermann 1978:71). Church polity might prevent the survival of the fittest in the ecclesiastical community.

This stresses the misunderstanding and/or the incapacity to overcome injustice and to reach peace, and to see that law serves and is not a goal in itself. The same goes for church polity. It might not save you, but at least it protects you, but if so, it also protects the rights of others, and of the community. So, does law create peace? 'Of course', says Demel (2009), a German expert in canon law:

Was für eine Frage! Was denn sonst! Denken Sie nur daran, was wäre, wenn es nicht das Recht auf Leben, das Recht auf Eigentum, das Recht auf religiöse Freiheit gabe und deshalb jeder Mörder, jede Diebin und jede religiöse Zwangsausübung unbestraft bliebe? Was für ein Unfriede würde hersschen! (p. 12)

She refers to the Greek philosopher Sophocles (496-406 BC) who preached 'When I have the law by my side, your threat does not fright me!' (Demel 2009:12). Occasionally, she points out the very nature of a church order as an order of freedom and peace [in German: Freiheits-und Friedensordnung]. Moreover, church polity also creates peace in the sense of reconciliation. This includes restoration of what has been broken. It is not sweet peace or just peace for an individual soul, or that the relationship between one person and God is restored. It should include restoration of the broken relationship(s) in the faith community. This does not come easy. It is not a moment, but a process. Alongside the action that needs to be taken by church members and office-bearers, there is also the promise of peace and reconciliation as a gift of God. This also comes in structures, although they are imperfect, or the application in ecclesiastical practice is far from perfect. Church order is an instrument to help to realise peace and reconciliation. It is an assignment for the church and the church receives it as a gift from God. The German Roman-Catholic theologian Konrad Hilpert states that law is 'eine präventive und strukturelle Umsetzung des biblischen Versöhnungsauftrags' (Hilpert 1999:875). Demel adds, 'und damit ein wesentlicher Beitraf zum Frieden' (Demel 2009:14). The German priest and canonist Audomar (Konrad) Scheuermann (1908-2000) compared the nature of a church order with the function of the skeleton of the human body (Demel 2005:73-74; Scheuermann 1978:71). There cannot be human life without a skeleton, even though the skeleton is invisible. Therefore, it is not difficult to overlook, ignore or to ridicule it, until a piece of the skeleton is broken or has been removed. 
Church polity is not (only) about order, nor is it about a book of church order, and not even about the church. Von Campenhausen (1959) considered:

Die Kirche entsteht nicht durch die Ordnung und lebt nicht von der rechten Ordnung, sondern allein in Christi Geist; wenn sie aber geistlich lebt, dann ist und kommt sie auch in Ordnung, dann stellt sie durch den Geist des Friedens auch die rechte Ordnung in ihrer Mitte her, ohne sich an diese Ordnung zu verkaufen. (p. 6)

Coertzen (1998:24) wrote, 'From the peace experienced in Christ with God an order flows that must be maintained by the congregation as an embodiment of the peace with God and with one another'. Coertzen (1998:91) refers to Calvin (Institutes IV.10.27) who argues for the preservation of the general peace and to maintain harmony' (Coertzen 1998:91). It is interesting to see a resemblance with the aim of peace and harmony in the above-mentioned canon 287 of the CIC. The preservation of the general peace and to maintain harmony is not a guarantee of spiritual maturity. The same goes for a good church order. Despite the church's high ideal, people in and outside the church grieve over the absence of the application of this high ethical ideal. Words like 'peace' and 'order' can easily be used as container terms, worn down, empty or without meaning. It is not difficult to become cynical abou such keywords, even when it appears that the statesman, lawyer and philosopher Marcus Tellus Cicer (106 BC-43 BC) has stated, 'The highest justice creates the highest injustice' (Cicero 1928:34). ${ }^{1}$ Nevertheless, Coertzen (1998:46) firmly stated that a good church order 'at least creates the space for the revelation of Gods justice and peace'. Or to put it into the words of Von Campenhausen (1959):

Es kommt darauf an, daß die Kirche vom Wort, vom Geist und vom Frieden Gottes her lebt und von da aus - wie es Paulus fordert - ihre Ordnung findet und bestimmt, von selbst oder auch mit Hilfe bewußter, ruhiger und sachlicher Überlegungen in Ordnung bleibt oder in Ordnung kommt. (p. 8)

If the office-bearers and church members give that up, they give up the church, and the peace.

\section{Conclusion}

It seems that the word 'peace' is rarely present in one or more of the old church orders, except for the Dordt Church Order of 1619 and in some of its revisions up until the present. Also, the meaning of serving peace in section A2 is not clear at first glance. The response of the church order committee of the Reformed Churches Liberated reveals something of both the origin and the meaning of the said section. In addition, it connects with the nature of order. It needs to be an order of peace, not only in the sense of order or good and friendly interpersonal relationships in the church, and eventually and confidently the restoration in cases of disorder and disunity. References in church polity and church order to biblical passages are essential that the eschatological dimension of peace should not be forgotten. The God of love and peace works through the Holy Spirit and overcomes all brokenness

1.A similar sentence appears by the playwright Publius Terentius Afer (195/185-159? $\mathrm{BC}$ ), Heautontimorumenos, IV, 5 , 'lus summum saepe summa est malitia' (supreme justice is often out of supreme malice [or wickedness]). in and outside the church. Good church polity aims to be biblical, by referring to 1 Corinthians $14: 33$ and 40 , and to James 3:18, although not in the sense of a paper pope. It needs to be applied in the church which exists in an imperfect and broken world. In this sense, as Von Campenhausen (1959) pointed out, Philippians 4:8f is also a gift and an assignment for the church:

Auch die Ordnung in der Kirche, der Wille, all das zu fördern, was ehrbar, was gerecht, was keusch, was lieblich ist und wohllautet, muß als eine Frucht des Heiligen Geistes bejaht werden, und so, sagt der Apostel Paulus, wird auch der Gott des Friedens mit uns sein [...]. (p. 25)

The opposite of disorder is indeed not order, but peace: sjalom or eirène. Peace can be restored by law and/or church polity, even outside paradise. Not because it is just a task, but because of its very nature and that according to the bible, church and church polity, the faithful ought to be 'peacemakers who sow in peace reap a harvest of righteousness'.

\section{Acknowledgements}

Allan J. Janssen (1948-2020).

\section{Competing interests}

The author declares that he has no financial or personal relationships that may have inappropriately influenced him in writing this article.

\section{Author's contribution}

L.v.d.B. is the sole author of this research article.

\section{Ethical considerations}

This article followed all ethical standards for research without direct contact with human or animal subjects.

\section{Funding information}

This research received no specific grant from any funding agency in the public, commercial or not-for-profit sectors.

\section{Data availability}

Data sharing is not applicable to this article as no new data were created or analysed in this study.

\section{Disclaimer}

The views and opinions expressed in this article are those of the author and do not necessarily reflect the official policy or position of any affiliated agency of the author.

\section{References}

Acta, [1578] 1978, 'Acta ofte handelinghe des nationalen synodi der Nederlandischen Duytschen ende Walschen kercken, soo wel inlandischen als uutlandischen, begonnen te Dordrecht den $3^{\text {en }}$ unii ende gheeyndicht den 18 des selfden maents in den jen 1578', in D. Nauta \& J. Van Dheen in den jare 1578, in D. Nauta \& J.P. Van Door (eds.), De nationale synode va Dordrecht 1578. Gereformeerden uit de noordelijke en de zuidelijke Nederlanden bijeen, pp. 142-184, Buijten \& Schipperheijn/Ton Bolland, Amsterdam. 
Anderson, R., 2012, 'Dean, 1 Korintiërs: Orde op zaken in een jonge stadskerk', in J. van Bruggen (ed.), Commentaar op het Nieuwe Testament, vol. 3, Kok, Kampen.

Bible Study Tools n.d., New International Version (NIV), viewed 02 June 2020, from https://www.biblestudytools.com/niv/.

Billerbeck, P., 1985, Die briefe des Neuen Testaments und die Offenbarung Johannis erläutert aus Talmud und Midrasch, 8th edn., Kommentar zum Neuen Testament aus Talmud und Midrasch, vol. 3, C.H. Beck'sche Verlagsbuchhandlung, München.

Bos, F.L., 1950, De orde der kerk, toegelicht met kerkelijke bes/uiten uit vier eeuwen, 's, Guido de Bres, Gravenhage.

Bouwman, H., 1934, Gereformeerd kerkrecht: Het recht der kerken in de practijk, vol. 2., Kok, Kampen.

Bronkhorst, A.J., 1947, Schrift en kerkorde: Een bijdrage tot het onderzoek naar de mogelijkheid van een 'schriftuurlijke kerkorde', N.V. Zuid-Holl, Boek- en Handelsdrukkerij, Den Haag.

Coertzen, P., 1998, Church and order: A reformed perspective, Peeters, Leuven.

De Gier, K., 1989, De Dordtse kerkorde: Een praktische verklaring, Den Hertog, Houten.

Demel, S., 2009, Spiritualitat des Kirchenrechts, Münsterschwarzacher Kleinschriften 173, Vier-Turme-Verlag, Münsterschwarzach.

Deputaten herziening kerkorde, 2009, Ontwerp kerkorde met generale regelingen voor de Gereformeerde Kerken (vrijgemaakt) in Nederland [Werkorde 1], in opdracht van de Generale Synode Zwolle-Zuid 2008.

Deputaten herziening kerkorde, 2011, Ontwerp kerkorde -2 tekst en toelichting met vermelding van generale regelingen WERKORDE 2: Nader ontwerp kerkorde voor de Gereformeerde Kerken (vrijgemaakt) in Nederland in opdracht van de generale synode Zwolle-Zuid 2008, opgesteld door deputaten herziening kerkorde.

DKO, 1619, Kercken-ordeninge; Gestelt indê Nationalen Synode der Ghereformeerde Kercken /te samen beroepen / eñ gehouden by laste vande Hooghmo: Heeren Staten Generael van de Vereenighde Nederlanden/ Binnen Dordrecht, inden lar 1618. ende 1619. Ende alsoo goet ghevonden ende gearresteert by de Ed: Mo: Heeren Staten s'Landts van VTRECHT. Opden vj. Augusti des voorsz laers 1619, 1620 , Salomon de Roy, Utrecht.

Dombois, H., 1969, Das Recht der Gnade I: Ökumenisches Kirchenrecht, 2nd edn. Forschungen und Berichte der Evangelischen Studiengemeinschaft 20, LutherVerlag, Witten.

Garland, D.E., 2003, 1 Corinthians, Baker Exegetical Commentary on the New Testament, Baker Academic, Grand Rapids, MI

Gingrich, F.W. \& Danker, F.W., 1979, A Greek-English lexicon of the New Testament and other early Christian literature: A translation and adaption of the fourth revised
and augmented edition of Walter Bauer's Griechisch-Deutsches Wörterbuch zu and augmented edition of Walter Bauer's Griechisch-Deutsches Wörterbuch zu
den Schriften des Neuen Testaments und der übrigen urchristlichen Literatur, 2nd edn., The University of Chicago Press, Chicago, IL.

Hilpert, K., 1999, 'Recht VI. Theologisch', Lexicon für Theologie und Kirche 8, Freiburg /Br.3, 873-876.

Jansen, J., 1952, Korte verklaring van de kerkorde der Gereformeerden Kerken, 3rd. edn., Kok, Kampen.

Jefford, C.N., 2013, Didache: The teaching of the twelve apostles, Early Christian Apocrypha 5: Didache, Polebridge Press, Salem, OR.

Jenni, E. \& Westermann, C., 1984, Theologisches Handwörterbuch zum Alten Testament 2, Chr. Kaiser Verlag/Theologischer Verlag, München/Zürich.

Kerkorde, 1586, 'Kercken-ordeninghe der Nederlandtsche Ghereformeerde Kercken van beyder talen, ghestelt inden Nationalen Synode, Te samen beroepen ende ghehouden by last van zijn Excelentie, in s' Graven-Haghe den 20 lunii Anno 1586', in F.L. Rutgers (ed.), Acta van de Nederlandsche Synoden der zestiende eeuw, 2nd edn., pp. 487-507, J.P. Van den Tol, Dordrecht.

Kerkorde CGK, 2011, Kerkorde van de Christelijke Gereformeerde Kerken in Nederland. Het laatst gewijzigd en aangevuld door de generale synode Huizen/Nunspeet 2010, Buijten \& Schipperheijn Motief, Amsterdam.

Kerkorde GKN, 1892, Kerken-ordening, gesteld in de Nationale Synode der Gereformeerde Kerken gehouden te Dordrecht in de jaren 1618 en 1619, zooals die onderhouden wordt door de Gereformeerde Kerken in Nederland, en door deze bij de Overheid is bekend gemaakt, volgens het besluit der Generale Synode van Amsterdam in den jare 1892, in: Acta der Generale Synode van De Gereformeerde Kerken in Nederland, gehouden te Dordrecht in den jare 1893, pp. 231-243, J.A. Wormser, Amsterdam.

Kerkorde GKN, 1905, Generale Synode van Utrecht, 'Kerkenordening van de Gereformeerde Kerken in Nederland; met de wijzigingen, die daarin zijn aangebracht door de Generale Synode te Utrecht in Augustus 1905', in Acta der Generale Synode van de Gereformeerde Kerken in Nederland, gehouden te Utrecht van 22 Augustus tot 7 September 1905, pp. 323-337, Boekhandel voorheen Höveker \& Wormser, Amsterdam.

Kerkorde GKN, 1933, Generale Synode van Middelburg, 'Kerkenordening van de Gereformeerde Kerken in Nederland', in Acta der Generale Synode van de Gereformeerde Kerken in Nederland gehouden te Middelburg van 22 Augustus tot 8 September 1933, pp. 310-320, J.H. Kok N.V., Kampen.
Kerkorde GKN, 1957, 'Kerkorde van de Gereformeerde Kerken in Nederland', in Acta van de Generale Synode van Assen 1957 en 1958 van de Gereformeerde Kerken in vederland gehouden te Assen van 27 augustus 1957 - 10 oktober 1957, van 14 april $1958-7$ mei 1958, en te Utrecht op 26 juni 1958, J.H. Kok N.V., Kampen.

Kerkorde GKN, 1971, Kerkorde van de Gereformeerde Kerken in Nederland, vastgesteld door de generale synode van Assen (1957) met de door volgende synoden daarin a angebrachte wijzigingen en aangevuld met een aantal annexe bepalingen aangebrachte wijzigingen Kok N.V., Kampen.

Kerkorde GKv, 1978, Acta van de Generale Synode Amersfoort-Centrum 2005 van de Gereformeerde Kerken in Nederland, Bijlage XVII - I: Tekst van de geldende kerkorde, Deputaten Generaal-Synodale Publicaties, s.I.

Kerkorde GKv, [1971] 2017, Kerkorde van de Gereformeerde Kerken in Nederland zoals vastgesteld door de Generale Synode van Ede 2014 en nadien gewijzigd door de Generale Synode van Meppel 2017 met transponeringstabel en overzicht van wijzigingen, s.n., s.l.

Koffeman, L.J., 2014, In order to serve: An ecumenical introduction to church polity, Church Polity and Ecumenism: Global Perspectives 1, LIT Verlag, Zürich.

Lockwood, G.J., 2000, 1 Corinthians, Concordia commentary: A theological exposition of sacred scripture, Concordia Publishing House, Saint Louis, MO.

Orr, W.F. \& Walther, J.A., 1976, 1 Corinthians A new translation. Introduction with a study of the life of Paul, Notes and Commentary, The Anchor Bible, New York, Doubleday \& Company Inc., Garden City, NY.

Pop, F.J., 1974, De eerste brief van Paulus aan de Corinthiers, De prediking van het Nieuwe Testament, 2nd edn., Callenbach, Nijkerk.

Ridderbos, H.N., 1965, 'Kerkordelijke orde en kerkelijk recht in de brieven van Paulus', in G.C. Berkouwer \& R. Schippers (eds.), Ex Auditu Verbi: Theologische opstellen aangeboden aan Prof. Dr. G.C. Berkouwer ter gelegenheid van zijn vijfentwintigjarig ambtsjubileum als hoogleraar in de Faculteit der Godgeleerdheid van de Vrije Universiteit te Amsterdam, pp. 194-215, Kampen, Kok.

Ridderbos, H.N., 1966, Paulus: Ontwerp van zijn theologie, Kok, Kampen.

Roukema, R., 1996, De uitleg van Paulus' eerste brief aan de Corinthiërs in de tweede en derde eeuw, Kok, Kampen.

Rutgers, F.L., 1980, Acta van de Nederlandsche synoden der zestiende eeuw: verzameld en uitgegeven door F.L. Rutgers., reprint, 2 nd edn., J.P. van den Tol, Dordrecht.

Rutgers, F.L., 1892, Bespreking der hoofdpunten van het Kerkrecht naar aanleiding van de Dordtsche Kerkenorde, in J. de Jong (ed.), s.I., s.n.

Scheuermann, A., 1978, 'Die Rechtsgestalt der Kirche', in W. Sandfuchs (ed.), Die Kirche: Fünfzehn Betrachtungen, pp. 69-82, s.n., Würzburg.

Schrage, W., 1999, Der Erste Brief an die Korinther, 3. Teilband 1 Kor.11,17-14:40, Evangelisch-Katholischer Kommentar zum Neuen Testament VII/3, Benziger Verlag, Zurich

Senft, C., 1979, La Première Epitre de Saint-Paul aux Corinthiens, Commentaire du Nouveau Testament, deuxième serie VII, Delachaux \& Niestlé, Neuchatel.

Smit, C.J., 1984, God se orde vir sy kerk: 'n Beskouking oor kerkorde, NG Kerkboekhandel Transvaal, Pretoria.

Spoelstra, B., 1989, Gereformeerde kerkreg en kerkregering: 'n Handboek by die Kerkorde, Hammanskraal: Die Hammanskraalse Teologiese Skool van die Gereformeerde Kerke in Suid-Afrika, Pretoria.

The Canon Law Society, 1984, Code of Canon Law = Codex Iuris Canonici: Latin English ed. (CIC 1984), transl. Canon Law Society of Great Britain and Ireland, assisted by the Canon Law Society of Australia and New Zealand and the Canadian Canon Law Society, The Canon Law Society, Washington, DC.

Torfs, R., 2002, De kardinaal heeft verdriet, Van Halewijck, Leuven.

Tullius Cicero, M., 1928, Cicero de Officiis, transl. Walter Miller, 3rd edn., William Heinemann/G.R. Putnam's Sons, New York, NY.

Van den Broeke, L., 2018, 'The composition of reformed church orders: A theological, reformed and juridical perspective', In die Skriflig 52(2), a2351. https://doi.org/ 10.4102 /ids.v52i2.2351

Van den Broeke, L. \& Schaeffer, J.H.F., 2019, Geest of recht? Kerkrecht tussen ideaa en werkelijkheid, Deddens Kerkrecht Serie 3, Summum Academic Publications, Kampen.

Van der Walt, J.J., 1974, 'Christus as Hoof van die Kerk en Art. 46 van die Kerkorde', In die Skriflig 8(34), 5-9. https://doi.org/10.4102/ids.v8i32.1034

Van Rongen, G., 2005, Decently and in Good Order: The Church Order of Dordrecht as revised by Synod Rockingham 2003 of The Free Reformed Churches of Australia commented on Armadale, 3rd edn., The Reformed Guardian New Series 21 , s.l., s.n.

Visser, J., 1999, Die Kerkorde in Praktyk, Eigen Beheer, Roodepoort.

Von Campenhausen, H.F., 1953, Kirchliches amt und geistliche vollmacht in den ersten drie jahrhunderten, Beiträge zur Historischen Theologie 14, Verlag J.C.B. Mohr (Paul Siebeck), Tübingen.

Von Campenhausen, H.F. \& Bornkamm, H., 1959, Bindung und Freiheit in der Ordnung der Kirche: Zwei Vorträge, Sammlung gemeinverständlicher Vorträge und Schriften aus dem Gebiet der Theologie und Religionsgeschichte 222/223, J.C.B. Mohr (Paul Siebeck), Tübingen. 